\title{
Milyen volt az Egészségfejlesztés 2018-as éve? Olvasottsági rekord után szavazás az év legjobb cikkéről
}

\author{
Year 2018 for Journal of Health Promotion \\ Record high attendance and vote for the best article of the year
}

doi: $\quad 10.24365 /$ ef.v59i6.394

Kedves Olvasók!

Hogy melyik volt az év cikke? Erről az Önök véleményét szeretnénk kérni, ezért szavazást indítunk az idei legjobb közlemény kiválasztására, a legtöbb szavazatot nyert cikk első szerzőjével pedig interjút közlünk a 2019/1-es számban. Olvasóink visszajelzése fontos számunkra a lap minél magasabb színvonalú megjelentetéséhez, bátorítunk tehát minden olvasót, hogy szavazzon az „Egészségfejlesztés legjobb 2018-as cikke” dijazottjára és biztassa erre munkatársait is!
Hogy a szerkesztőknek mi a véleménye a 2018-as évről? Büszkén jelenthetjük, hogy az év elején meghirdetett expanziót sikerrel teljesítettük. Először a folyóirat történetében két különszámot is megjelentettünk a szokásos négy mellett. Ezúton is köszönjük a tavaszi és az őszi különszámok vendégfőszerkesztőinek, Túri Gergőnek és Soósné Dr. Kiss Zsuzsannának, hogy vállalták a lapszámok összeállításával járó szokatlan szakmai feladatokat. Ugyancsak köszönet illeti azokat az elkötelezett szakembereket, akik a kéziratok szakbírálatában részt vettek. [1. táblázat]

Az Egészségfejlesztés 2018-as közleményeinek listája: https://goo.gl/ezWm8E

Szavazás: https://goo.gl/forms/07uq5ksWewiEcwYY2

1. táblázat: Szakemberek, akik szakbírálatukkal támogatták közleményeink megjelenését

\begin{tabular}{|l|l|}
\hline Bánfalvi Attila & Debreceni Egyetem \\
\hline Balázs Péter & Semmelweis Egyetem \\
\hline Bárdos Helga & Debreceni Egyetem \\
\hline Csizmadia Péter & Nemzeti Népegészségügyi Központ \\
\hline Erdősi Erika & Szegedi Tudományegyetem \\
\hline Fogarasi András & Bethesda Gyermekkórház \\
\hline Girán János & Pécsi Tudományegyetem \\
\hline Göndör Éva & Széchenyi István Egyetem \\
\hline Harmat György & Semmelweis Egyetem \\
\hline Juhász Zoltán & Szegedi Tudományegyetem \\
\hline Kiss István & Pécsi Tudományegyetem \\
\hline Laky Marcella & Semmelweis Egyetem \\
\hline Mák Erzsébet & Semmelweis Egyetem \\
\hline Németh Anikó & Szegedi Tudományegyetem \\
\hline Őri Adrienne & Jász-Nagykun-Szolnok Megyei Hetényi Géza Kórház-Rendelőintézet \\
\hline Pakai Annamária & Pécsi Tudományegyetem \\
\hline Pilling János & Semmelweis Egyetem \\
\hline Rajki Veronika & Semmelweis Egyetem \\
\hline Tobak Orsolya & Szegedi Tudományegyetem \\
\hline Tulkán Ibolya & Szegedi Tudományegyetem \\
\hline Veress Réka & HEPA Europe \\
\hline Vitrai József & Nemzeti Népegészségügyi Központ \\
\hline
\end{tabular}


A folyóirat szerzői közössége és az általuk képviselt intézmények köre is jelentősen kibővült köszönhetően többek között a különszámokban először közlő szerzőknek. Joggal feltételezhető, hogy a folyóiratban publikáló szerzők és az olvasók ma már valójában képviselik a hazai egészségfejlesztésben tevékenykedő szakembereket. A szerzők számának emelkedése természetesen együtt járt a laphoz benyújtott kéziratok gyarapodásával: ebben az évben 170-nél több kézirat ment át a szerkesztés folyamatán, míg 2017-ben még csupán 85.

A lap olvasottsági statisztikái - az előbbiektől talán nem függetlenül - ebben az évben is javultak [1. ábra és 2. táblázat]: novemberben közel hússzor többen jártak a lap honlapján, mint az elektronikus folyóirat első számának megjelenésekor. A folyóirat honlapját naponta meglátogatók havi átlaga az év végén már 330 fölé is kúszott, de volt két olyan nap is, amikor 12 órás nappalra vetítve minden percben (720) kattintott egy olvasó a folyoirat.nefi.hu-ra. Köszönjük! A kitartóan növekvő érdeklődés egyértelmű jelzés a szerkesztők felé arra, hogy az olvasóközönség részéről van igény az egészségfejlesztéssel kapcsolatos szakmai információk megismerésére.

Az év utolsó napjaira gondűző pihenést és egyben kellemes ünnepeket kívánunk olvasóinknak!

Egészségfejlesztés szerkesztősége

\section{1. ábra: A lap látogatottsága}

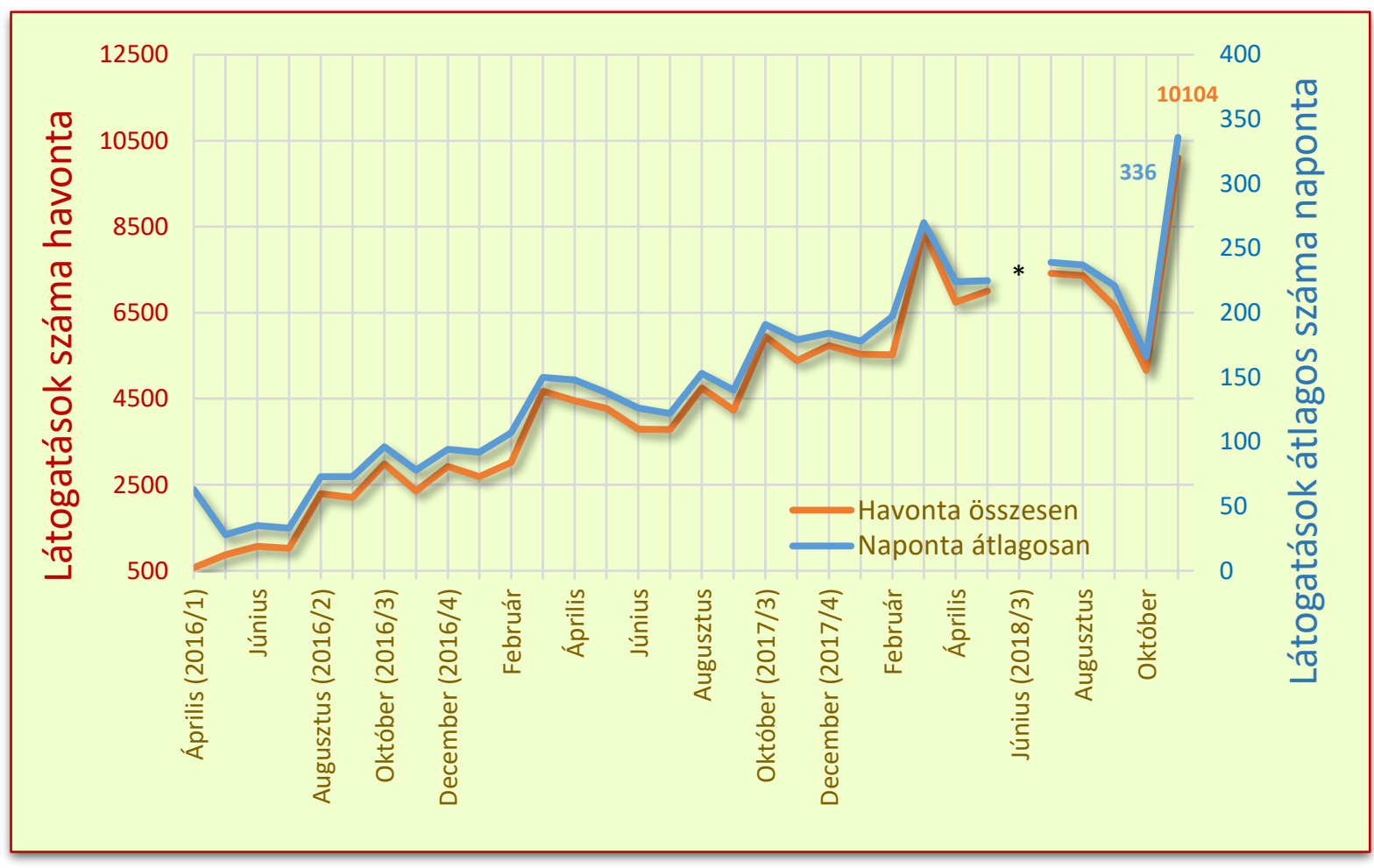

* nincs adat 


\begin{tabular}{|c|c|c|c|}
\hline $\begin{array}{l}\text { Megte- } \\
\text { kintések } \\
\text { száma }\end{array}$ & Közlemény címe & Szerzők & Lapszám \\
\hline \multicolumn{2}{|c|}{ ÖSSZEFOGLALÓ } & & \\
\hline 645 & Egészséges életmóddal kapcsolatos kutatások a hazai iskolákban & $\begin{array}{l}\text { Járomi É, Szilágyi K, } \\
\text { Vitrai J }\end{array}$ & 2016. 1. \\
\hline 525 & Hazai egészség-pillanatkép, 2017 & $\begin{array}{l}\text { Vitrai J, Bakacs M, } \\
\text { Varsányi P }\end{array}$ & 2017. 4. \\
\hline 521 & A kortársbántalmazás (bullying) mint népegészségügyi probléma & $\begin{array}{l}\text { Várnai D, Zsíros E, } \\
\text { Németh Á }\end{array}$ & 2016. 4. \\
\hline 502 & $\begin{array}{l}\text { A 2015/2016. tanév országos fittségmérési eredményei a Nemzeti Egységes Ta- } \\
\text { nulói Fittségi Teszt (NETFIT }{ }^{\oplus} \text { ) alapján }\end{array}$ & Csányi T, Kaj M & 2017. 4. \\
\hline 445 & $\begin{array}{l}\text { A gyógytestnevelés jelentősége a szekunder rehabilitáció és egészségfejlesztés } \\
\text { folyamatában, megújulásának szükségessége, irányai }\end{array}$ & Simon I, Kajtár G & 2018. 1. \\
\hline 427 & $\begin{array}{l}\text { Egészpályás letámadás a kövérség ellen - Komplex beavatkozásokkal az elhízás } \\
\text { visszaszorítására }\end{array}$ & Vitrai J, Bakacs M & 2017. 4. \\
\hline 404 & $\begin{array}{l}\text { Magyarország népegészségügyi rendszere és egészségfejlesztéssel foglalkozó } \\
\text { szervezetei }\end{array}$ & Túri G et al. & 2018. 2. \\
\hline 391 & $\begin{array}{l}\text { Kortárs egészségfejlesztési programok gyermekek és fiatalok körében a hazai } \\
\text { és a nemzetközi szakirodalom tükrében - Szisztematikus áttekintés }\end{array}$ & Lukács-Jakab Á et al. & 2018. 1. \\
\hline 390 & Új hazai egészségmonitorozási koncepció & Varsányi P et al. & 2016. 1. \\
\hline 385 & Miért van szükségünk közösségalapú egészségfejlesztésre? & Benyó B & 2017. 4. \\
\hline \multicolumn{2}{|c|}{ TELUES KÖZLEMÉNY } & & \\
\hline 2807 & A csecsemőkori allergia-megelőzés korszerú irányelvei és lehetőségei & Réthy $A$ & 2017. 1. \\
\hline 1007 & Egészségfejlesztési Irodák hálózata & Bezzegh P & 2016. 1. \\
\hline 819 & Egészséges életmóddal kapcsolatos kutatások a hazai iskolákban & $\begin{array}{l}\text { Járomi É, Szilágyi K, } \\
\text { Vitrai J }\end{array}$ & 2016. 1. \\
\hline 584 & Hazai egészség-pillanatkép, 2017 & $\begin{array}{l}\text { Vitrai J, Bakacs M, } \\
\text { Varsányi P }\end{array}$ & 2017. 4. \\
\hline 541 & OKOSTÁNYÉR ${ }^{\circledR}$ - új táplálkozási ajánlás a hazai felnőtt lakosság számára & Szűcs Zs & 2016. 4. \\
\hline 357 & $\begin{array}{l}\text { Magyarország népegészségügyi rendszere és egészségfejlesztéssel foglalkozó } \\
\text { szervezetei }\end{array}$ & Túri G et. Al & 2018. 2. \\
\hline 357 & Az iskolai egészségfejlesztés hazai és nemzetközi szemléletének bemutatatása & Járomi É, Vitrai J & 2017. 1. \\
\hline 309 & Amerikai Táplálkozási Ajánlás 2015-2020 - rövid ismertetés & Fekete K, Henter I & 2016. 2. \\
\hline 306 & $\begin{array}{l}\text { Összefoglaló „A munkahelyi egészségfejlesztés általános szervezeti megvalósí- } \\
\text { tására vonatkozó szakmai útmutató”-ról }\end{array}$ & Solymossy J, Koós T & 2016. 3. \\
\hline 303 & 2016-os Éves Jelentés a kábítószerhelyzetről - rövid összefoglaló & Nyírády A & 2016. 4. \\
\hline \multicolumn{2}{|c|}{ "ÉRDEKESSÉG" } & & \\
\hline 4,83 & Az anyai attitűdöt befolyásoló családi tényezők & Pachner o, Lendvay Zs & 2018. 5. \\
\hline 4,53 & A csecsemőkori allergia-megelőzés korszerű irányelvei és lehetőségei & Réthy A & 2017. 1. \\
\hline 3,00 & A családi tradíció szerepe a kisdedek és kisgyermekek táplálkozásában & $\begin{array}{l}\text { Karácsonyi I, Kölkedi } \\
\text { P, Karamánné Pakai A }\end{array}$ & 2018. 5. \\
\hline 2,62 & Új Gondozástan tankönyv & & 2018. 5. \\
\hline 2,39 & $\begin{array}{l}\text { Hogyan előzzük meg a gyermekbántalmazást? A prevenciós munka jelentősége } \\
\text { és kihívásai }\end{array}$ & Toma A et al. & 2018. 5. \\
\hline 1,73 & Köszöntő & & 2018. 5. \\
\hline 1,73 & $\begin{array}{l}\text { Magyarország népegészségügyi rendszere és egészségfejlesztéssel foglalkozó } \\
\text { szervezetei }\end{array}$ & Túri G et al. & 2018. 2. \\
\hline 1,67 & Hazai egészség-pillanatkép, 2017 & $\begin{array}{l}\text { Vitrai J, Bakacs M, } \\
\text { Varsányi P }\end{array}$ & 2017. 4. \\
\hline 1,59 & $\begin{array}{l}\text { Családon belüli szociális, mentálhigiénés kompetenciák fejlesztésével szerzett } \\
\text { tapasztalataink egészségügyi alapszakos felsőoktatási hallgatók körében }\end{array}$ & Fodor B, Kiss.Tóth E & 2018. 5. \\
\hline 1,55 & $\begin{array}{l}\text { A városi egészségfejlesztési tervezés mint a „lehetőségek ablakát” megnyitó } \\
\text { eszköz - Székesfehérvár város példája }\end{array}$ & Girán J & 2018. 3. \\
\hline
\end{tabular}

